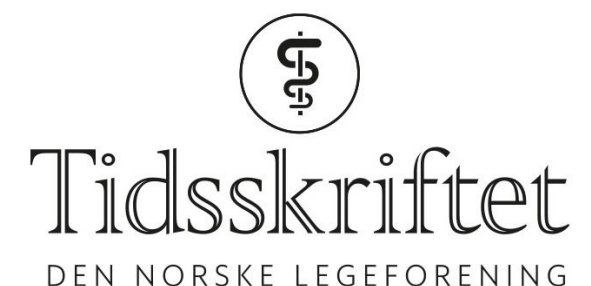

DEN NORSKE LEGEFORENING

\title{
Alle typer hjerneslag må gjenkjennes prehospitalt
}

DEBATT

\section{MAREN RANHOFF HOV}

E-post: maren.ranhoff.hov@norskluftambulanse.no Maren Ranhoff Hov er lege, ph.d., førsteamanuensis ved Paramedisinutdanningen, OsloMet, lege i spesialisering i nevrologi ved seksjon for hjerneslag ved Nevrologisk avdeling, Oslo universitetssykehus, og seniorforsker i Stiftelsen Norsk Luftambulanse. Forfatteren har fylt ut ICMJE-skjemaet og oppgir ingen interessekonflikter.

\section{MONA GUTERUD}

Mona Guterud er ambulansearbeider ved Prehospital avdeling, Oslo universitetssykehus, M.Sc. i Prehospital Critical Care og ph.d.-stipendiat ved Oslo universitetssykehus og Stiftelsen Norsk Luftambulanse.

Forfatteren har fylt ut ICMJE-skjemaet og oppgir ingen interessekonflikter.

\section{HELGE FAGERHEIM BUGGE}

Helge Fagerheim Bugge er lege i spesialisering i nevrologi ved seksjon for hjerneslag ved Nevrologisk avdeling, Oslo universitetssykehus, og ph.d.-stipendiat i Stiftelsen Norsk Luftambulanse. Forfatteren har fylt ut ICMJE-skjemaet og oppgir ingen interessekonflikter.

\section{KARIANNE LARSEN}

Karianne Larsen er spesialist i nevrologi og ph.d.-stipendiat i Stiftelsen Norsk Luftambulanse. Forfatteren har fylt ut ICMJE-skjemaet og oppgir ingen interessekonflikter.

\section{KRISTI C.G. BACHE}

Kristi C.G. Bache er ph.d., forskningssjef ved Stiftelsen Norsk Luftambulanse og forsker ved Institutt for medisinske basalfag, Universitetet i Oslo. Forfatteren har fylt ut ICMJE-skjemaet og oppgir ingen interessekonflikter.

\section{KJELL OTTO FREMSTAD}

Kjell Otto Fremstad er ambulansearbeider og ansatt ved Prehospital avdeling, Oslo universitetssykehus. Han er M.Sc. i Prehospital Critical Care og seksjonsleder for utdanning i Stiftelsen Norsk Luftambulanse.

Forfatteren har fylt ut ICMJE-skjemaet og oppgir ingen interessekonflikter.

\section{ELSE CHARLOTTE SANDSET}

Else Charlotte Sandset er ph.d., overlege ved seksjon for hjerneslag ved Nevrologisk avdeling, Oslo universitetssykehus, generalsekretær i den europeiske slagorganisasjonen (ESO) og seniorforsker i Stiftelsen Norsk Luftambulanse.

Forfatteren har fylt ut ICMJE-skjemaet og oppgir ingen interessekonflikter. 
Ambulansetjenesten ønsker og trenger et standardisert verktøy i møte med slagpasienten, og et språk som forstås av mottagende sykehusleger.

I sykehusene finnes spesialiserte slagteam som står klare når pasienter blir meldt inn med mistenkt hjerneslag. Men den progressive celleskaden som startes ved en intracerebral blødning eller blodpropp venter imidlertid ikke på at pasienten blir innlagt. Den skjer umiddelbart, hjemme hos pasienten, på arbeidsplassen - prehospitalt. Prehospital forhåndsvarsling til riktig behandlingsnivå er avgjørende for vellykket revaskularisering, og forsinkelser er meget uheldig for pasientens prognose. Forsinkelse i den prehospitale delen av sykdomsforløpet hos slagpasienter står for $50 \%$ av den totale forsinkelsen ved sykehusinnleggelse (1), og kan i stor grad tilskrives manglende kompetanse og fortolkning av symptombildet ved akutt hjerneslag (2). Vi mener det er på tide å introdusere The National Institutes of Health Stroke Scale (NIHSS) prehospitalt.

\section{Ingen kompetansekrav}

Europeiske retningslinjer for slagbehandling anbefaler sterkt prehospital forhåndsvarsling, da dette reduserer tiden til reperfusjonsbehandling. Nasjonal retningslinje for behandling og rehabilitering ved hjerneslag har ingen krav til kliniske undersøkelser, verktøy for beslutning om leveringssted eller prehospitale kompetansekrav (3). Retningslinjen anmoder til opprettelse av "prehospital varsling, trombolysealarm og et trombolyseteam som står klart når pasienten ankommer sykehuset» og at det er opp til det enkelte sykehuset hvordan dette organiseres. Prosedyre for identifiseringen av pasientgruppen som innfrir kriteriet om prehospital varsling av trombolyseteam er ikke beskrevet.

Både over- og undertriage er uheldig for pasientens prognose og ressursfordelingen i den akuttmedisinske kjeden

Prehospitalt arbeid omfatter klinisk vurdering og beslutning om (riktig) behandlingsnivå såkalt triagering. Upresis triagering kan føre til overtriage med for høy respons i forhold til sykdomsalvorlighet, eller undertriage der responsen er for lav. Både over- og undertriage er uheldig for pasientens prognose og ressursfordelingen i den akuttmedisinske kjeden (4). Internasjonal forskning på prehospital triagering av slagpasienter har fokusert på korrekt seleksjon til høyeste behandlingsnivå, et regionalt intervensjonssenter med trombektomi. Ifølge Norsk hjerneslagregister ble bare $6,3 \%$ av pasientene med hjerneinfarkt behandlet med trombektomi i 2019(5).

\section{Mulig prehospitalt verktøy}

En prospektiv observasjonsstudie fra 2021 ser på åtte prehospitale kliniske slagskalaer for identifisering av pasienter med storkarokklusjon (6). Målet er økt presisjon i prehospital triagering og direkte transport til intervensjonssenter. Skalaene som presenteres er tilpasset identifisering av en liten andel slagpasienter, noe som kan gi undertriagering av de som ikke er rammet av storkarokklusjon - altså majoriteten av hjerneslagpasientene. Samtidig mener vi at innføringen av slike verktøy er svært uheldig for utviklingen av prehospital kompetanse innen hjerneslag. Studien konkluderer med at de prehospitale skalaene til en viss grad kan brukes til triagering, men at den mest anvendte inhospitale skalaen NIHSS kommer best ut (7).Vi lurer da på hvorfor NIHSS ikke blir ansett som et mulig prehospitalt verktøy?

NIHSS har gjennom mange år med gjentatt validering vist seg å være den kliniske skalaen som i størst grad identifiserer pasienter rammet av hjerneslag, også storkarokklusjoner (7). I Norge og internasjonalt, er likevel FAST (Fjes, Arm, Språk, Tid) mest brukt for vurdering av slagsymptomer utenfor sykehus. En FAST-skåring har høy sensitivitet $(81 \%)$ men lav spesifisitet (14\%) (8), fordi den i mindre grad vil avdekke andre symptomer enn motoriske utfall og taleforstyrrelser (7). Tidligere studier har vist at sensitiviteten for identifisering av hjerneslag blant ambulansepersonell er lav, kun $52 \%$ (9), noe som understreker behovet for standardiserte kompetansemål og strukturerte kliniske beslutningsstøtteverktøy (2). 


\section{Store variasjoner}

Kompetanse i gjenkjennelse av hjerneslagsymptomer er en forutsetning for prehospital forhåndsvarsling. Det er i dag store variasjoner mellom regionale helseforetak, de ulike ambulansetjenestene og blant utøvende ambulansepersonell. Hov og medarbeidere viste i 2018 at NIHSS kunne utføres av trente anestesileger prehospitalt, med høy grad av samsvar med slaglegers vurderinger (10). Dette ga vitenskapelig grunnlag for videre utvikling av NIHSS i ambulansetjenesten, og de første dataene kommer i løpet av 2021 fra vårt arbeid i en spesialisert slagambulanse. Videre pågår en randomisert studie ledet av prehospital klinikk og nevroklinikken ved Oslo universitetssykehus der ambulansepersonell bruker NIHSS gjennom en spesialutviklet operativ applikasjon (ParaNASPP-app). Vi mener at denne typen standardisert opplæring kan bidra til kompetanseøkning og gi aktørene i akutt hjerneslagbehandling et felles klinisk språk, både pre- og inhospitalt. Samtidig vil studien undersøke om prehospital NIHSS kan brukes som verktøy for direktetriagering til intervensjonssenter.

NIHSS har gjennom mange år med gjentatt validering vist seg å være den kliniske skalaen som i størst grad identifiserer pasienter rammet av hjerneslag

Den mulige helsegevinsten av et felles klinisk språk i den akutte hjerneslagkjeden er betydelig i byer med kort transportavstand til sykehus, men langt større i rurale deler av landet hvor luftambulanseressurser ofte vil være en forutsetning for rask transport til behandling. Vi håper at vår helhetlige kompetansemodell med prehospital NIHSS kan bidra til en strømlinjeformet slagsløyfe, med bedre kommunikasjon, presis triagering og detaljert klinisk informasjon og symptomovervåkning som starter allerede prehospitalt. Vi mener det er på høy tid med utredning av kompetansekrav og kliniske beslutningsverktøy for vurdering av akutt hjerneslag utenfor sykehus, slik at flere pasienter rammet av hjerneslag kan få akutt behandling.

\section{LITTERATUR:}

1. Faiz KW, Sundseth A, Thommessen B et al. Prehospital delay in acute stroke and TIA. Emerg Med J 2013; 30: 669-74. [PubMed][CrossRef]

2. Brandler ES, Sharma M, McCullough F et al. Prehospital stroke identification: factors associated with diagnostic accuracy. J Stroke Cerebrovasc Dis 2015; 24: 2161-6. [PubMed][CrossRef]

3. Helsedirektoratet. Nasjonal retningslinje for behandling og rehabilitering ved hjerneslag. https://www.helsedirektoratet.no/retningslinjer/hjerneslag Lest 1.6.2021.

4. Ryan JL, Pracht E, Langland-Orban B et al. Association of mechanism of injury with overtriage of injured youth patients as trauma alerts. Trauma Surg Acute Care Open 2019; 4: eooozoo.

[PubMed][CrossRef]

5. Norsk hjerneslagsregister: Årsrapport 2018 med plan for forbedringstiltak. Trondheim: St. Olavs hospital, 2019 .

https://www.kvalitetsregistre.no/sites/default/files/1_arsrapport_2018_hjerneslag_o.pdf Lest 1.6.2021.

6. Duvekot MHC, Venema E, Rozeman AD et al. Comparison of eight prehospital stroke scales to detect intracranial large-vessel occlusion in suspected stroke (PRESTO): a prospective observational study. Lancet Neurol 2021; 20: 213-21. [PubMed][CrossRef]

7. El Khoury R, Jung R, Nanda A et al. Overview of key factors in improving access to acute stroke care. Neurology 2012; 79 (suppl 1): S26-34. [PubMed][CrossRef]

8. Rudd M, Buck D, Ford GA et al. A systematic review of stroke recognition instruments in hospital and prehospital settings. Emerg Med J 2016; 33: 818-22. [PubMed][CrossRef]

9. Williams TA, Blacker D, Arendts G et al. Accuracy of stroke identification by paramedics in a metropolitan prehospital setting: a cohort study. Australasian Journal of Paramedicine 2017; 14. doi: 10.33151/ajp.14.2.521. [CrossRef] 
10. Hov MR, Røislien J, Lindner T et al. Stroke severity quantification by critical care physicians in a mobile stroke unit. Eur J Emerg Med 2019; 26:194-8. [PubMed][CrossRef]

Publisert: 25. juni 2021. Tidsskr Nor Legeforen. DOI: 10.4045/tidsskr.21.0241 Mottatt 8.4.2021, første revisjon innsendt 23.4.2021, godkjent 1.6.2021.

(C) Tidsskrift for Den norske legeforening 2020. Lastet ned fra tidsskriftet.no 